\title{
Relationship Between Secondary Amyloidosis and Carotid Intima Media Thickness in Inflammatory Disease
}

\author{
(1) Uğur Arslantaş, (10 Ersin Engin Şimsek, ${ }^{2}$ (1) Mustafa Bulut, \\ (1) Nimet Bilge Kalkan, ${ }^{2}$ (1) Selçuk Pala'
}

'Department of Cardiology, Kartal Koşuyolu Training and Research Hospital, İstanbul, Turkey ${ }^{2}$ Department of Family Medicine, Kartal Dr. Lütfü Kırdar Traning and Research Hospital, İstanbul, Turkey

Submitted: 30.01.2018 Accepted: 11.05.2018

Correspondence: Uğur Arslantaş, Kartal Koşuyolu Yüksek İhtisas Eğitim ve Araştırma Hastanesi, Kardiyoloji Kliniği, İstanbul, Turkey E-mail:u.ars@yandex.com

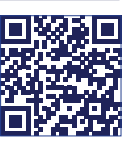

Keywords: Atherosclerosis; familial Mediterranean fever, systemic serum amyloid $A$ amyloidosis; carotid artery; intima-media thickness.

\begin{abstract}
Objective: Inflammation takes significant part in the pathogenesis of atherosclerosis and secondary amyloidosis but little is known about its relationship with both. Assessment of this relationship via carotid intima-media thickness (IMT) in patients with secondary amyloidosis and suitable controls, is the aim of our study.
\end{abstract}

Methods: 14 amyloidal inflammatory disease patients, 34 non-amyloidal inflammatory disease patients and 34 healthy volunteers formed the study population. All patients were nonsmoker. Patient with history of atherosclerotic vascular disease and presence of diabetes mellitus excluded the study. Investigating the measuring IMT from carotid arteries using ultrasonography was managed to assess subclinical atherosclerosis and CRP levels were measured from the all study population.

Results: Amyloidal inflammatory disease patients demonstrated a significantly greater carotid IMT $(0.7 \mathrm{I} \pm 0.8 \mathrm{~mm})$ compared with the non-amyloidal inflammatory disease patients $(0.56 \pm 0.1 \mathrm{~mm} ; \mathrm{p}<0.00 \mathrm{I})$ and the healthy controls $(0.43 \pm 0.4 \mathrm{~mm} ; \mathrm{p}<0.00 \mathrm{I})$. The patients with amyloidal inflammatory disease had a significantly greater CRP level $(5.7 \pm 2.5 \mathrm{mg} / \mathrm{L})$ than the other groups $(3.7 \pm 3.1 \mathrm{mg} / \mathrm{L}, \mathrm{I} .5 \pm 1.2 \mathrm{mg} / \mathrm{L} ; \mathrm{p}<0.00 \mathrm{I})$.

Conclusion: Increased carotid arterial wall thickness was associated with the presence of amyloidosis, perhaps due to an increase in atherosclerotic changes related to chronic lowlevel inflammation.

\section{INTRODUCTION}

Amyloid $\mathrm{A}(\mathrm{AA})$ amyloidosis and atherosclerosis are 2 different diseases, but uncontrolled inflammation plays a significant part in the pathogenesis of both. ${ }^{[l-3]}$ Amyloidosis is characterized by the extracellular deposition of a protein-like material and classified according to a precursor protein. Secondary AA amyloidosis is a complication of chronic inflammatory disorders, such as familial Mediterranean fever (FMF) and ankylosing spondylitis (AS), ${ }^{[4,5]}$ in which the amyloid fibrils are derived from serum amyloid A (SAA) protein. SAA, like C-reactive protein (CRP) is produced in the liver in response to proinflammatory cytokines. ${ }^{[6]}$ Patients with inflammatory diseases, such as those with FMF, AS, and systemic lupus erythematous, are considered to have an increased risk for secondary AA amyloidosis and atherosclerosis. ${ }^{[7,8]}$

Inflammation plays a significant part in the pathogenesis of both diseases, but little is known about the relationship. Carotid intima-media thickness (IMT) is used to define preclinical atherosclerosis. ${ }^{[7,8]}$ Therefore, the objective of this research was to determine whether inflammatory disease patients with AA amyloidosis have a greater risk of subclinical atherosclerosis than inflammatory disease patients without AA amyloidosis or healthy controls by assessing carotid IMT.

\section{MATERIAL AND METHODS}

This was a cross-sectional, observational study. After the 
study protocol was approved by the hospital ethics committee, a total of 82 participants were studied. There were 14 inflammatory disease patients with AAA (6 AS, 8 FMF), 34 inflammatory disease patients without AAA (16 AS, 18 FMF), and 34 sex, age, and excluded-criteria matched healthy controls.

All of the patients were non-smokers and at least 18 years of age. Patients with a history of atherosclerotic vascular disease (myocardial infarction, stroke, or peripheral vascular disease), uncontrolled hypertension, diabetes mellitus, malignancy, tuberculosis, acute/chronic infection, or chronic kidney disease were excluded. All of the FMF patients were on colchicine treatment $(1.5 \mathrm{mg} / \mathrm{day})$. The diagnosis of FMF was made according to the Tel Hashomer criteria $^{[9]}$ and the diagnosis of AS was made according to the modified New York criteria. ${ }^{[10]}$

Based on renal biopsy findings, 8 FMF patients and 6 AS patients were diagnosed with AA amyloidosis $(n=14)$. Healthy participants were chosen according to the study exclusion criteria.

All of the participants provided a complete history and had a physical examination. Clinical and laboratory assessments of patient with inflammatory disease were performed during an attack-free period, defined based on a lack of clinical symptoms. Blood sampling was carried out after an overnight fast. Laboratory variables of glucose, creatinine, C-reactive protein (CRP), and total cholesterol (T-Chol), high-density lipoprotein (HDL), and low-density lipoprotein (LDL) were measured using routine methods. Body mass index (BMI) was calculated by dividing weight (kilograms) by height (meters squared). Creatinine clearance $(\mathrm{CrCl})$ was calculated according to the CockcroftGault formula. ${ }^{[1]}$

\section{Carotid intima-media thickness measurement}

Bilateral assessment was made of wall thickness in the common carotid artery (CCA). Carotid IMT was measured as the distance from the leading edge of the first echogenic line (intima interface) to that of the second echogenic line (upper layer of the tunica adventitia). Carotid IMT measurement of both the right and left CCA was performed at 3 points on the far walls in each CCA from I cm proximal to the bifurcation of the CCA. The 3 locations were then averaged to produce a mean IMT for each side. The carotid IMT was reported as the average thickness of both CCAs.

\section{Statistical analysis}

All analyses were conducted using SPSS for Windows, Version 15.0 (SPSS, Inc., Chicago, IL, USA) and the mean \pm SD or median (interquartile range) was used to present the data, as applicable. The mean differences between groups were compared using one-way analysis of variance or the
Kruskal-Wallis test, according to the distribution. A post hoc Tukey Honest Significant Difference test was used to determine which group differed from the others. A twosided $p$ value of $<0.05$ was considered statistically significant.

\section{RESULTS}

The study population included 26 FMF, 22 AS patients, and 34 healthy participants. The 14 members of the amyloidal inflammatory disease group were $8 \mathrm{FMF}$ and 6 AS patients. Table I provides a summary of the clinical features and laboratory values of all of the study groups. Differences between groups as to age, sex, $\mathrm{BMI}, \mathrm{CrCl}$, systolic blood pressure, diastolic blood pressure, serum level of T-Chol, LDL, HDL, or fasting blood glucose, were not significant. T-Chol, LDL, HDL, fasting glucose, and creatine were measured at normal intervals. Serum CRP levels were significantly higher in the patients with amyloidal inflammatory disease compared with the control group $(p<0.00 \mathrm{I})$ (Table I).

The carotid CRP difference was statistically higher in amyloidal inflammatory disease patients $(p<0.00 \mathrm{I})$. As shown in Figure I and Table 2, the carotid IMT was determined to be significantly greater in the amyloidal inflammatory disease patients when compared with the non-amyloidal inflammatory disease patients and the healthy controls $(p<0.00 \mathrm{I})$. The amyloidosis patients had a higher IMT measurement as well as a higher CRP level compared with the non-amyloidal inflammatory disease patients $(0.70$ $\mathrm{mm}$ [range: $0.65-0.80 \mathrm{~mm}$ ] vs. $0.60 \mathrm{~mm}$ [range: $0.50-0.60$ $\mathrm{mm}$ ], $\mathrm{p}<0.00 \mathrm{I} ; 6.7 \mathrm{mg} / \mathrm{L}$ [range: $2.95-13.9 \mathrm{mg} / \mathrm{L})$ vs. 0.65 $\mathrm{mg} / \mathrm{L}$ (range: $0.33-\mathrm{l} .02 \mathrm{mg} / \mathrm{L}, \mathrm{P}<0.00 \mathrm{I}$ ), and the non-amyloidal inflammatory disease patients had a greater IMT and CRP when compared with the healthy participants $(0.60$

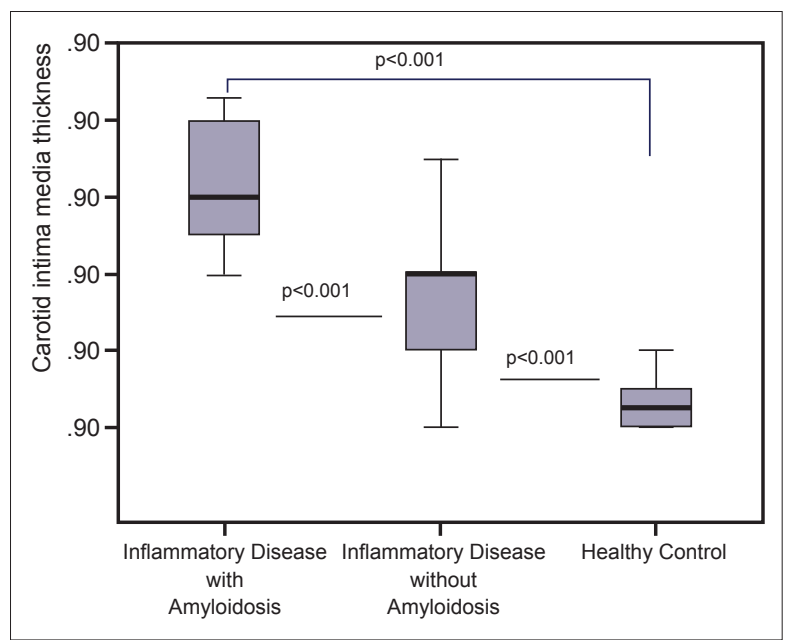

Figure 1. Mean carotid intima media thickness in familial Mediterranean fever (FMF) and ankylosing spondylitis (AS) patients with amyloidosis, FMF and AS without amyloidosis, and the healthy group. 
Table I. Clinical and laboratory characteristic of patient with or without amyloidosis and healthy controls

\begin{tabular}{|c|c|c|c|c|c|c|c|}
\hline & \multicolumn{2}{|c|}{$\begin{array}{c}\text { Inflammatory } \\
\text { disease with } \\
\text { amyloidosis }(n=14)\end{array}$} & \multicolumn{2}{|c|}{$\begin{array}{c}\text { Inflammatory } \\
\text { disease without } \\
\text { amyloidosis }(n=34)\end{array}$} & \multicolumn{2}{|c|}{$\begin{array}{c}\text { Healthy } \\
\text { subjects } \\
(n=34)\end{array}$} & \multirow[t]{2}{*}{$\mathbf{p}^{*}$} \\
\hline & $\mathbf{n}$ & $\%$ & $\mathbf{n}$ & $\%$ & $\mathbf{n}$ & $\%$ & \\
\hline Age (years) & 44.8 & 13.2 & 37.5 & 12 & 37.8 & 5.9 & 0.66 \\
\hline Male & 8 & 57.1 & 17 & 50 & 17 & 50 & 0.34 \\
\hline Body mass index $\left(\mathrm{kg} / \mathrm{m}^{2}\right)$ & 26 & 3 & 25 & 4 & 27 & 2 & 0.28 \\
\hline Diastolic blood pressure $(\mathrm{mmHg})$ & 77 & 9.6 & 77.4 & 7 & 75.8 & 6 & 0.67 \\
\hline Systolic blood pressure (mmHg) & 116 & 17.3 & 122 & 12.2 & 117.1 & 10 & 0.19 \\
\hline Creatinine (mg/dL) & I & 0.1 & 1 & 0.1 & 0.9 & 0.1 & 0.30 \\
\hline Creatinine clearance (mL/min) & 95.5 & 20.3 & 102.3 & 23.1 & 112.2 & 21.7 & 0.57 \\
\hline Total cholesterol (mg/dL) & 185.6 & 38.6 & 180 & 38.6 & 176.8 & 25.8 & 0.71 \\
\hline Low-density cholesterol (mg/dL) & 109.6 & 28.1 & 110.9 & 26.8 & III & 25.5 & 0.98 \\
\hline High-density cholesterol (mg/dL) & 46.7 & 15.8 & 43.2 & 9.1 & 42.6 & 9.7 & 0.46 \\
\hline Triglyceride (mg/dL) & 147.4 & 59.2 & 122 & 58.9 & 124.7 & 55.3 & 0.33 \\
\hline Fasting blood glucose (mg/dL) & 94.5 & 19.5 & 93.2 & 5.8 & 91.4 & 7.2 & 0.59 \\
\hline C-reactive protein (mg/dL) & 5.7 & 2.5 & 3.7 & 3.1 & 1.5 & 1.2 & $<0.001$ \\
\hline
\end{tabular}

Table 2. Ultrasound findings

\begin{tabular}{|c|c|c|c|c|c|c|c|}
\hline & \multicolumn{2}{|c|}{$\begin{array}{l}\text { Inflammatory } \\
\text { disease with } \\
\text { amyloidosis }\end{array}$} & \multicolumn{2}{|c|}{$\begin{array}{l}\text { Inflammatory } \\
\text { disease without } \\
\text { amyloidosis }\end{array}$} & \multicolumn{2}{|c|}{$\begin{array}{c}\text { Healthy } \\
\text { subjects } \\
(n=34)\end{array}$} & \multirow[t]{2}{*}{$\mathbf{p}^{*}$} \\
\hline & $\mathbf{n}$ & $\%$ & $\mathbf{n}$ & $\%$ & $\mathbf{n}$ & $\%$ & \\
\hline Ejection fraction (\%) & 64.2 & 3.4 & 67.1 & 4.7 & 66.8 & 2.9 & 0.54 \\
\hline Left ventricle diastolic diameter (mm) & 48.1 & 2 & 45.3 & 3.5 & 45.4 & 3.6 & 0.20 \\
\hline Left ventricle systolic diameter (mm) & 31.2 & 1.6 & 29 & 2.7 & 29.1 & 2.2 & 0.11 \\
\hline Mitral E (m/s) & 67.4 & 18.4 & 76.5 & 18 & 76.8 & 13.4 & 0.17 \\
\hline Mitral A (m/s) & 65 & 20 & 69.7 & 13.8 & 61.1 & 11.7 & 0.60 \\
\hline Carotid intima media thickness & 0.71 & 0.8 & 0.56 & 0.1 & 0.43 & 0.4 & $<0.001$ \\
\hline
\end{tabular}

$\mathrm{mm}$ [range: $0.50-0.60 \mathrm{~mm}$ ] vs. $0.45 \mathrm{~mm}$ [range: $0.40-0.50$ $\mathrm{mm}$ ], $\mathrm{p}<0.00 \mathrm{I} ; 0.65 \mathrm{mg} / \mathrm{L}$ [range: $0.33-\mathrm{l} .02 \mathrm{mg} / \mathrm{L}$ ] vs. 0.43 $\mathrm{mg} / \mathrm{L}$ [range $0.40-0.46 \mathrm{mg} / \mathrm{L}], \mathrm{p}=0.04)$.

\section{DISCUSSION}

The results of this study demonstrated that the carotid IMT was significantly greater in the patients with amyloidal inflammatory disease than in those with non-amyloidal inflammatory disease and the healthy participants. To the best of our knowledge, this is the first study to demonstrate an association between amyloidosis and carotid IMT in inflammatory disease patients matched for major atherosclerotic risk factors.
Atherosclerosis is a slow, progressive inflammatory disease. The presence of atherosclerosis can be identified using various noninvasive imaging techniques, such as measuring carotid IMT with ultrasound, which is a widely accepted screening method of subclinical atherosclerosis. ${ }^{[2]}$ Excessive carotid IMT is associated with atherosclerosis in the coronary arteries. ${ }^{[13]}$ Previous studies have demonstrated that patients with inflammatory disease have greater carotid IMT levels, and our results, which revealed an increased carotid IMT in the group with inflammatory disease, are consistent with previous study data. ${ }^{[7,8]}$ The study data were collected with care and matched for major risk factors for atherosclerosis, including smoking status and diabetes mellitus. 
According to our findings, AA amyloidosis was associated with carotid IMT, though there are several possible explanations for the relationship observed between carotid arterial wall thickness and $A A$ amyloidosis. First, there is a possible association between AA amyloidosis and inflammation. Systemic AA amyloidosis is a long-recognized, severe complication of several chronic inflammatory diseases. Inflammatory diseases and atherosclerosis share a number of similarities, including inflammatory cell activation and the production of pro-inflammatory cytokines. [14-16] Patients with inflammatory diseases have an elevated level of CRP, a marker of inflammation relevant to increased cardiovascular risk. ${ }^{[1,17]}$ Among various markers of inflammation, CRP level was suggested as a particularly powerful predictor of cardiovascular disease independent of serum lipid levels in a general population study in the United States. ${ }^{[14]}$ It is also hypothesized that CRP may be causally involved in the pathophysiology of atherosclerosis and its complications. ${ }^{[1]]}$ Tanasescu et al. ${ }^{[18]}$ reported that the IMT of inflammatory disease patients was correlated with CRP level. Secondary amyloidosis occurs in $5 \%$ of patients with poorly controlled chronic inflammatory disease, mainly AS and FMF. ${ }^{[2,19]}$ The low-level inflammatory reaction may lead to an increase in arterial wall thickness. As supporting data, we also found that the mean CRP level was greater in the inflammatory disease patient group without amyloidosis than in the healthy control group. However, the highest mean CRP level was in the group of inflammatory disease patients who had amyloidosis.

A second feasible explanation for the increased IMT in amyloidosis patients may be SAA. SAA is a major inflammatory molecule and $A A$ amyloid fibrils are derived from SAA. ${ }^{[20]}$ An elevated level of circulating SAA is present in secondary amyloidosis patients as well as patients with atherosclerosis. ${ }^{[2]]}$ SAA has been suggested as a marker of atherosclerotic disease and it has been found in many cell types in atherosclerotic lesions. ${ }^{[22-24]}$ SAA level was not measured in our study, and represents an issue that should be addressed in future research.

The third cause may renal involvement in AA amyloidosis. This can be a cause of proteinuria, nephrotic syndrome, and/or renal dysfunction. ${ }^{[25]}$ The results of a large cohort study and a meta analysis indicated that sustained decreases in estimated glomerular filtration rate (eGFR) below $60 \mathrm{~mL} /$ minute $/ 1.73 \mathrm{~m}^{2}$ were associated with increased rates of atherosclerotic diseases. ${ }^{[26,27]}$ Furthermore, studies have described increased cardiovascular mortality and morbidity risk in renal disease associated with amyloidosis. [28-30] In this study, AA amyloidosis patients were diagnosed based on renal biopsy findings, and the mean level of blood creatinine and eGFR were in the normal range, with no significant difference between groups; however, we calculated the eGFR using the Crockcroft-Gault formula and it may not be accurate in patients with factors affecting creatinine production because serum creatinine is a main component of the formula. Direct measurement of $\mathrm{CrCl}$ using 24-hour urine creatinine clearance data would be helpful in a similar population group in future studies.

Amyloidosis series reported from Turkey are generally associated with FMF, but in the colchicine-treatment era, FMF patients with amyloidosis are becoming extremely rare and it is difficult to recruit cases. ${ }^{[4]}$ Therefore, the number of patients in the amyloidosis group was relatively small and the study groups consisted of mixed inflammatory disease patients.

\section{Conclusion}

Our results suggested that increased arterial wall thickness is associated with the presence of amyloidosis, possibly due to an increase in atherosclerotic changes related to inflammation. In order to confirm these correlations, prospective studies with a larger number of participants are warranted.

\section{Ethics Committee Approval}

Approved by the local ethics committee.

\section{Informed Consent}

Retrospective study.

Peer-review

Internally peer-reviewed.

Authorship Contributions

Concept: U.A, S.P.; Design: U.A, E.E.Ş.; Data collection \&/ or processing: U.A., N.B.K..; Analysis and/or interpretation: U.A., N.B.K.; Literature search: U.A., N.B.K.; Writing: U.A., N.B.K., S.P.; Critical review: U.A., M.B., S.P., E.E.Ş.

Conflict of Interest

None declared.

\section{REFERENCES}

1. Koenig W. High-sensitivity C-reactive protein and atherosclerotic disease: from improved risk prediction to risk-guided therapy. Int J Cardiol 2013;168:5126-34.

2. Pepys MB. Amyloidosis. Annu Rev Med 2006;57:223-41.

3. Ross R. Mechanisms of atherosclerosis-a review. Adv Nephrol from Necker Hosp 1990;19:79-86.

4. Kasifoglu T, Bilge SY, Sari I, Solmaz D, Senel S, Emmungil H, et al: Amyloidosis and its related factors in Turkish patients with familial Mediterranean fever: a multicentre study. Rheumatology (Oxford) 2014;53:741-5.

5. Dönmez S, Pamuk ÖN, Pamuk GE, Aydoğdu E, Inman R. Secondary amyloidosis in ankylosing spondylitis. Rheumatology Int 2013;33:1725-9.

6. Uhlar CM, Whitehead AS. Serum amyloid A, the major vertebrate acute-phase reactant. European journal of biochemistry / FEBS 1999;265:501-23.

7. Gupta N, Saigal R, Goyal L, Agrawal A, Bhargava R, Agrawal A. 
Carotid intima media thickness as a marker of atherosclerosis in ankylosing spondylitis. Int J Rheumatol 2014; 2014:839135.

8. Ugurlu S, Seyahi E, Cetinkaya F, Ozbakir F, Balci H, Ozdogan H. Intima-media thickening in patients with familial Mediterranean fever. Rheumatology (Oxford) 2009;48:911-5.

9. Livneh A, Langevitz P, Zemer D, Zaks N, Kees S, Lidar T, et al. Criteria for the diagnosis of familial Mediterranean fever. Arthritis and rheumatism 1997;40:1879-85.

10. van der Linden S, Valkenburg HA, Cats A. Evaluation of diagnostic criteria for ankylosing spondylitis. A proposal for modification of the New York criteria. Arthritis Rheum 1984;27:361-8.

11. Cockcroft DW, Gault MH. Prediction of creatinine clearance from serum creatinine. Nephron 1976;16:31-41.

12. de Groot E, van Leuven SI, Duivenvoorden R, Meuwese MC, Akdim F, Bots ML, et al. Measurement of carotid intima-media thickness to assess progression and regression of atherosclerosis. Nat Clin Pract Cardiovasc Med 2008;5:280-8.

13. Sibal L, Agarwal SC, Home PD. Carotid intima-media thickness as a surrogate marker of cardiovascular disease in diabetes. Diabetes Metab Syndr Obes 2011;4:23-34.

14. Danesh J, Whincup P, Walker M, Lennon L, Thomson A, Appleby P, et al. Low grade inflammation and coronary heart disease: prospective study and updated meta-analyses. BMJ 2000;321:199-204.

15. Duzova A, Bakkaloglu A, Besbas N, Topaloglu R, Ozen S, Ozaltin F, et al. Role of A-SAA in monitoring subclinical inflammation and in colchicine dosage in familial Mediterranean fever. Clin Exp Rheumatol 2003;21:509-14.

16. Hansson GK. Inflammation, atherosclerosis, and coronary artery disease. N Eng J Med 2005;352:1685-95.

17. Ridker PM, Glynn RJ, Hennekens CH. C-reactive protein adds to the predictive value of total and HDL cholesterol in determining risk of first myocardial infarction. Circulation 1998;97:2007-11.

18. Tanasescu C, Jurcut C, Jurcut R, Ginghina C. Vascular disease in rheumatoid arthritis: from subclinical lesions to cardiovascular risk. Eur J Intern Med 2009;20:348-54.

19. Mladenovic J, Geisic L, Kerimovic D, Arambasic M, Berovic Z. Incidence of amyloidosis in rheumatoid arthritis and ankylosing spondylitis. Scand J Rheumatol 1975;4:39.

20. Feghali CA, Wright TM. Cytokines in acute and chronic inflammation. Front Biosci 1997;2:d12-26.

21. Fyfe AI, Rothenberg LS, DeBeer FC, Cantor RM, Rotter JI, Lusis AJ. Association between serum amyloid A proteins and coronary artery disease: evidence from two distinct arteriosclerotic processes. Circulation 1997;96:2914-9.

22. Meek RL, Urieli-Shoval S, Benditt EP. Expression of apolipoprotein serum amyloid A mRNA in human atherosclerotic lesions and cultured vascular cells: implications for serum amyloid A function. Proc Natl Acad Scie U S A 1994;91:3186-90.

23. Ogasawara K, Mashiba S, Wada Y, Sahara M, Uchida K, Aizawa T, et al. A serum amyloid A and LDL complex as a new prognostic marker in stable coronary artery disease. Atherosclerosis 2004;174:349-56.

24. Yamada T. Serum amyloid A (SAA): a concise review of biology, assay methods and clinical usefulness. Clin Chem Lab Med 1999;37:3818.

25. Ozen S. Renal amyloidosis in familial Mediterranean fever. Kidney Int 2004;65:1118-27.

26. Go AS, Chertow GM, Fan D, McCulloch CE, Hsu CY. Chronic kidney disease and the risks of death, cardiovascular events, and hospitalization. N Eng J Med 2004;351:1296-305.

27. Chronic Kidney Disease Prognosis Consortium, Matsushita K, van der Velde M, Astor BC, Woodward M, Levey AS, de Jong PE, et al. Association of estimated glomerular filtration rate and albuminuria with all-cause and cardiovascular mortality in general population cohorts: a collaborative meta-analysis. Lancet 2010;375:2073-81.

28. Celik A, Saglam F, Dolek D, Sifil A, Soylu A, Cavdar C, et al. Outcome of kidney transplantation for renal amyloidosis:a single-center experience. Transplant Proc 2006;38:435-9.

29. Sanai T, Nanishi F, Nagata M, Hirano T, Suematsu E, Esaki Y, et al. Role of amyloidosis in determining the prognosis of dialyzed patients with rheumatoid arthritis. Rheumatology Int 2007;27:363-7.

30. Barzilay JI, Peterson D, Cushman M, Heckbert SR, Cao JJ, Blaum C, et al. The relationship of cardiovascular risk factors to microalbuminuria in older adults with or without diabetes mellitus or hypertension: the cardiovascular health study. Am J Kidney Dis 2004;44:25-34.

\section{Enflamatuvar Hastalıklarda Sekonder Amiloidoz ile Karotis İntima Media Kalınlığı İlişkisi}

Amaç: Ateroskleroz ve sekonder amiloidoz patogenezlerinde enflamasyonun çok önemli rolü olmasına rağmen, her iki hastalık arasındaki ilişki tam olarak bilinmemektedir. Bu çalışmanın amacı, karotis intima media kalınlığı (IMK) değerlendirerek, sekonder amiloidoz olan hastalarla, olmayan uygun kontrol gruplarında bu ilişkiyi incelemek.

Gereç ve Yöntem: Çalışma popülasyonu 14 amiloidoz gelişmiş enflamatuvar hastalıklı hasta ile 34 amiloidoz gelişmemiş enflamatuvar hastalıklı hasta ve 34 sağlıklı gönüllüden oluşmaktadır. Tüm hastalar sigara içmeyenlerden seçildi. Aterosklerotik damar hastalığı ve diyabetes mellitus tanısı olan hastalar çalışmaya alınmadı. Subklinik ateroskleroz B-mod ultrasonografı kullanılarak karotis arterden IMK ölçülerek değerlendirildi ve tüm hastaların CRP düzeyleri ölçüldü.

Bulgular: Korotis IMK istatiksel olarak anlamlı olarak, amiloidoz bulunan hastalarda $(0.71 \pm 0.8 \mathrm{~mm})$, bulunmayan hastalara $(0.56 \pm 0.1 \mathrm{~mm}$, $\mathrm{p}<0.00 \mathrm{I})$ ve sağılıkı kontrol grubuna $(0.43 \pm 0.4 \mathrm{~mm}, \mathrm{p}<0.00 \mathrm{I})$ göre daha kalın ölçüldü. Aynı zamanda C-reaktif protein düzeyleri de amiloidoz hastalarında $(5.7 \pm 2.5)$ kontrol gruplarına göre anlamlı olarak yüksek ölçüldü $(3.7 \pm 3.1$, I.5 51.2$)(p<0.00 I)$.

Sonuç: Amiloidoz hastalığııın varlığında bulunan artmış IMK, enflamasyona bağı gelişen aterosklerotik değişikliklere bağlı olabilir.

Anahtar Sözcükler: Ailevi Akdeniz ateşi; aterosklerosis; carotid artery; intima-media-thickness; sistemik amiloyidosis AA. 